\title{
Pengembangan Modul Biologi berbasis Reasoning and Problem Solving disertai Concept Mapping Tipe Network Tree pada Materi Pencemaran Lingkungan untuk Memberdayakan Keterampilan Proses Sains dan Kemampuan Mengevaluasi
}

\author{
The Development of Biology Module based on Reasoning and Problem \\ Solving with Network Tree Concept Mapping on the Environmental Pollution \\ Material to Empower Science Process Skills and Evaluation Abilities
}

\author{
YUSROH ALQURIYAH, SUCIATI, BASKORO ADI PRAYITNO \\ Program Studi Pendidikan Biologi FKIP Universitas Sebelas Maret \\ Jl. Ir. Sutami No. 36A Kentingan Surakarta \\ *email: yusyus90@gmail.com
}

Manuscript received: 18 Mei 2013 Revision accepted: 17 Juli 2014

\begin{abstract}
The objectives of this research and development are to investigate: 1) characteristic of biology module based on reasoning and problem solving (RPS) with network tree concept mapping (CM);2) feasibility of biology module based on RPS with network tree CM to empower science process skills and evaluation abilities; 3) effectiveness of biology module based on RPS with network tree CM toward science process skills; and 4) effectiveness of biology module based on RPS with network tree CM toward evaluation abilities. This research used the Research and Development (R\&D) which referred to the model claimed by Borg \& Gall (1983) with some modifications. The samples of the research included those of preliminary field testing which involved 7 validators, those of main field testing that involved 10 students, and those of operational field testing which involved 32 students. The operational field testing used the one group pretest and posstest design. The data of research were gathered through questionnaire, observation, interview, and test. The data of science process skills and evaluation abilities were tested by means of paired sample t-test and calculated by using normalized gain score. The results of research showed that: 1) the characteristics of biology module based on RPS with network tree CM are as follows: (a) the development uses the model claimed by Borg \& Gall with some modifications (research and information collecting, planning, development of preliminary form of product, preliminary field testing, main product revision, main field testing, operational product revision, operational field, final product revision, and dissemination and implementation); (b) module developed by RPSsyntax(read and think, explore and plan, select strategy, find and answer, dan reflect and extend);(c) module with network treeCM as a techniques of expansion and strengthening concept; (d) the learning activities in the module can empower science process skills and evaluation abilities; 2) the score of feasibility of biology module based on RPS with network tree CM is 3.27 , which is in the very good category; 3) the biology module based on RPS with network tree CM is effective to empower science process skills as indicated by the $\mathrm{N}$-gain score of 0.58 , which is in the moderate category; and 4) the biology module based on RPS with network tree $\mathrm{CM}$ is effective to empower evaluation abilities as signified by the $\mathrm{N}$-gain score of 0.30 , which is in the moderate category.
\end{abstract}

Keywords: module, reasoning and problem solving, neetwork tree concept mapping, science process skills, evaluation abilities

\section{LATAR BELAKANG}

Perkembangan sains dan teknologi di abad 21 menjadikan persaingan di segala bidang kehidupan semakin ketat, maka sekolah memiliki andil yang besar dalam menyelenggarakan pembelajaran yang berkualitas dengan mengembangkan potensi siswa melalui High Order Thinking Skills (HOTS) melalui pemberdayaaan kemampuan berpikir kritis. Salah satu mata pelajaran yang menuntut siswa dalam berpikir kritis adalah sains. Biologi merupakan bagian dari sains. Rustaman (2005) menyatakan bahwa konteks pendidikan biologi mengacu pada hakikat sains yaitu produk, proses, dan sikap melalui keterampilan proses. Yuniastuti (2013) mengemukakan bahwa pembelajaran biologi yang baik adalah pembelajaran yang dilandaskan pada prinsip keterampilan proses, dimana siswa dididik untuk menemukan dan mengembangkan sendiri fakta dan konsepnya sendiri.

Fakta di lapangan, pembelajaran biologi lebih berorientasi pada produk, sehingga keterampilan proses sains tidak tereksplor secara maksimal. Rendahnya kemampuan sains siswa terlihat dari survei Programme for Internasional Students Assesmentl PISA memperlihatkan bahwa dari 41 negara peserta, siswa Indonesia berada di urutan 2 terendah dari 65 negara yang disurvei dengan nilai rata-rata 382 tahun 2012. 
Permasalahan rendahnya kemam-puan sains siswa juga terjadi di SMAN 1 Karanganom. Hasil observasi lapangan menunjukkan bahwa proses pembela-jaran biologi yang dilakukan oleh guru cenderung menggunakan metode ceramah, dan didominasi dengan kegiatan presentasi kelompok serta penugasan individu melalui browsing internet. Teknik pengajaran guru sering kali menggunakan teknik pemetaan berupa bagan sehingga siswa merasa bosan. Hal tersebut diperkuat dengan hasil wawancara siswa yang menunjukkan bahwa proses pembelaja-ran biologi jarang melakukan praktikum di laboratorium. Pembelajaran teori tanpa melakukan praktikum membuat keterampilan proses sains siswa tidak terlatihkan, sehingga kurang terberdayakan secara maksimal.

Hasil analisis kebutuhan data awal menunjukkan bahwa bahan ajar yang digunakan oleh guru dan siswa adalah buku referensi dan LKS yang tidak sesuai dengan hakikat sains, karena hanya berisikan materi dan latihanlatihan soal yang kurang memberdayakan kemampuan berpikir kritis siswa. Latihan soal terbatas pada kemampuan menjelaskan sebesar $0,33 \%$, interpretasi sebesar $0,44 \%$, menyimpulkan sebesar $0,105 \%$, menganalisa sebesar $0,08 \%$, dan mengevaluasi sebesar $0,04 \%$. Pada jenjang evaluasi siswa mengalami kesulitan untuk menilai kredibilitas suatu pernyataan. Hal ini terbukti dengan kemampuan menilai klaim sebesar 0,025 $\%$ dan menilai argumen $0,017 \%$.

Kemampuan mengevaluasi sangat diperlukan oleh siswa ketika mereka dihadapkan pada suatu argumen, atau permasalahan yang menuntut mereka untuk memberikan penilaian. Hal tersebut sejalan dengan Crebert (2011) menyatakan bahwa kemampuan mengevalusi secara kritis sangat penting untuk membuktikan suatu tema/ isu, menafsirkan informasi, dan menyelesaikan masalah dalam menanggapi tantangan zaman.

Berdasarkan permasalahan tersebut, perlu dilakukan pembaharuan dalam proses pembelajaran biologi. Pembaharuan pembelajaran biologi berjalan optimal apabila didukung bahan ajar dan model pembelajaran yang tepat. Bahan ajar yang mampu membantu siswa dan guru dalam proses pembelajaran yaitu modul, sedangkan model pembelajaran yang mampu mengkonstruksi pengetahuan siswa adalah model pembelajaran berbasis kontruktivisme, salah satunya Reasoning and Problem Solving (RPS).

Model pembelajaran RPS menuntut siswa untuk memecahkan masalah berdasarkan strategi yang mereka pilih dengan alasan yang relevan serta rasional dengan permasalahan yang diberikan. Menurut Krulik dan Rudnick (1996), model RPS memiliki lima langkah pembelajaran antara lain: 1. read and think; 2. explore and plan; 3. select strategy; 4. find and answer; dan 5. reflect and extend. Tahapan-tahapan tersebut dimungkinkan mampu memberdayakan keterampilan proses sains dan kemampuan mengevaluasi siswa.

Model pembelajaran berjalan lebih efektif jika disertai dengan teknik ajar yang tepat. Salah satu jenis peta konsep yang mempermudah siswa dalam mendalami materi dan mempelajari bidang studi lebih bermakna adalah concept mapping tipe network tree, karena cocok digunakan untuk menunjukkan informasi sebab-akibat, suatu hierarki, prosedur yang bercabang, dan istilah-istilah yang berkaitan dan dapat digunakan untuk menjelaskan hubungan-hubungan. Perpaduan antara bahan ajar, model, dan teknik pembelajaran yang tepat diharapkan dapat mencapai tujuan pembelajaran biologi.

Bertolak dari latar belakang tersebut, maka perlu dikemukakan penelitian yang berjudul "Pengembangan Modul Biologi berbasis Reasoning and Problem Solving disertai Concept Mapping Tipe Network Tree pada Materi Pencemaran Lingkungan untuk Memberdayakan Keterampilan Proses Sains dan Kemampuan Mengevaluasi”.

\section{METODE}

Pengembangan modul biologi berbasis RPS mengacu pada model penelitian dan pengembangan (Research and Development) modifikasi dari Borg and Gall (1983), sebagai berikut: research and information collecting, planning, develop preliminary form of product, preliminary field testing, main product revision, main field testing, operational product revision, operational field, final product revision dan dissemination and Implementation.

Teknik pengumpulan data menggunakan observasi, angket, dan wawancara. Sampel penelitian pengembangan meliputi: sampel uji coba lapangan awal sejumlah 7 validator, sampel uji coba lapangan utama sejumlah 10 siswa, dan sampel uji coba lapangan operasional sejumlah 32 siswa. Uji coba lapangan operasional menggunakan one group pretest-postest design. Data keterampilan proses sains dan kemampuan mengevaluasi diuji dengan paired sample t-test dan dihitung menggunakan gain skor ternormalisasi.

\section{HASIL DAN PEMBAHASAN}

Hasil penelitian pengembangan ini diperoleh modul biologi berbasis model pembelajaran RPS disertai concept mapping tipe network tree pada materi pencemaran lingkungan untuk memberdayakan keterampilan proses sains (KPS) dan kemampuan mengevaluasi. Modul berbasis RPS disertai concept mapping tipe network tree telah melalui penilaian secara kualitatif dan kuantitatif yang kemudian direvisi berdasarkan masukan dari validator ahli, praktisi, dan siswa pada tahap uji coba lapangan awal, utama, dan operasional.

Tahap pengumpulan data diperoleh bahwa: 1) daya serap pada kemampuan menjelaskan keterkaitan antara kegiatan manusia dengan masalah perubahan/ pencemaran lingkungan siswa SMAN 1 Karanganom mengalami penurunan, yaitu pada tahun pelajaran 2011/ 2012 sebesar 87,21, sedangkan pada tahun 2012/ 2013 adalah sebesar 64,29 ; 2) terdapat GAP sebesar $11,13 \%$ pada analisis SNP; 3) lembar kerja siswa yang digunakan berasal dari 
MGMP Kabupaten Klaten yang hanya berisikan kumpulan materi dan latihan soal; 4) pembelajaran didominasi oleh guru; dan 5) teknik pemetaan yang monoton.

Tahap perencanaan melakukan penetapan Kurikulum 2013, perumusan indikator pencapaian kompetensi dan tujuan pembelajaran, bahan ajar yang dikembangkan berupa modul, model pembelajaran yang dipilih adalah RPS disertai concept mapping tipe network tree, dan penentukan prosedur terkait pengembangan modul yaitu melalui modifikasi dari desain penelitian dan pengembangan Borg and Gall. Tahap pengembangan produk awal membuat desain modul sesuai dengan tahapan RPS disertai concept mapping tipe network tree sebagai teknik ajarnya yang telah diintegrasikan dalam komponen modul sebagai modul draft I. Modul terdiri atas 3 bagian, yaitu: bagian awal, inti, dan penutup. Selanjutnya diujikan pada tahap uji lapangan awal.

Berdasarkan hasil yang diperoleh pada uji coba lapangan awal terkait kelayakan modul diperoleh rata-rata 3,47 untuk instrumen pembelajaran, 3,40 untuk aspek materi, 3,43 untuk aspek penyajian, 3,17 aspek keterbacaan, dan 3,58 untuk validasi modul oleh praktisi. Kategori yang diperoleh pada uji lapangan awal adalah sangat baik. Modul yang telah diujikan kemudian diperbaiki sesuai dengan masukan validator pada tahap revisi produk I. Perbaikan modul meliputi: penambahan materi yang bersal dari text book yang dipakai di perguruan tinggi, penambahan kunci jawaban, memperjelas sumber gambar maupun tulisan, penggantian contoh peta konsep, dan perbaikan tampilan modul secara keseluruhan.

Hasil uji coba lapangan utama diperoleh rata-rata 76,89 untuk aspek isi modul, 79,22 untuk aspek penyajian, dan 81,82 untuk aspek keterbacaan. Rata-rata ketiga aspek diperoleh 79,31 dengan kategori baik. Hasil peniaian secara keseluruhan dapat disimpulkan bahwa modul sudah layak untuk dilanjutkan pada tahap uji coba lapangan operasional. Perbaikan yang dilakukan pada tahap revisi produk II yaitu memperjelas gambar dan penambahan beberapa materi agar lebih lengkap tetapi dibuat dengan bahasa yang ringkas dan jelas sehingga mudah dipahami siswa.

Uji coba lapangan operasional menggunakan kelas $\mathrm{X}$ MIPA 2 SMAN 1 Karanganom sebanyak 32 siswa. Data yang diperoleh dalam tahap uji coba lapangan operasional terdiri atas: data keterlaksanaan langkah-langkah pembelajaran, data utama (data KPS dan kemampuan mengevaluasi), dan data hasil belajar (pengetahuan, sikap, dan keterampilan).

Selama proses pembelajaran keterlaksanaan langkahlangkah pembelajaran diperoleh rata-rata $87,50 \%$ untuk aktivitas guru dan dikategorikan sangat baik, sedangkan aktivitas siswa diperoleh rata-rata $83,24 \%$ dan dikategorikan sangat baik. Hasil penilaian modul oleh siswa diperoleh rata-rata pada aspek isi modul 3,14, aspek penyajian sebesar 3,37, aspek keterbacaan sebesar 3,31, sehingga dapat digolongkan dalam kategori sangat baik. Hasil belajar siswa menunjukkan rata-rata 86,41 untuk aspek pengetahuan, 83,69 untuk aspek sikap, dan 81,30 untuk aspek keterampilan.

Hasil uji efektivitas modul diperoleh dari data KPS dan kemampuan mengevaluasi melalui uji hipotesis dan nilai $N$-gain. Hasil analisis KPS disajikan pada Tabel 1 , sedangkan hasil analisis kemampuan mengevaluasi disajikan pada Tabel 2.

Tabel 1. Hasil Analisis KPS

\begin{tabular}{cccccc}
\hline No. & Jenis tes & Jenis Uji & Kig & Keputusan & Kesimpulan \\
\cline { 3 - 5 } & & & & \\
\hline & KPS & Kolmogorov-Smirnov Test & Pretes $=0,465$ & Sig $>0.05$ & Data normal \\
1. & Normalitas & Postes $=0,429$ & Sig $>0,05$ & Data normal \\
& & Lig=0,156 & Sig $>0,05$ & Data homogen \\
2. & Homogenitas & Paired sample T-Test & Sig $=0,000$ & Sig $<0,05$ & Hasil tidak sama (berbeda) \\
\hline 3
\end{tabular}

Tabel 2. Hasil Analisis Kemampuan Mengevaluasi

\begin{tabular}{|c|c|c|c|c|c|}
\hline \multirow[t]{2}{*}{ No. } & \multirow[t]{2}{*}{ Jenis tes } & \multirow[t]{2}{*}{ Jenis Uji } & \multicolumn{2}{|c|}{ KPS } & \multirow[b]{2}{*}{ Kesimpulan } \\
\hline & & & Sig & Keputusan & \\
\hline 1. & $\begin{array}{c}\text { Evaluasi } \\
\text { Normalitas }\end{array}$ & Kolmogorov-Smirnov & $\begin{array}{l}\text { Pretes }=0,823 \\
\text { Postes }=0,711\end{array}$ & $\begin{array}{l}\text { Sig }>0.05 \\
\text { Sig }>0,05\end{array}$ & $\begin{array}{l}\text { Data normal } \\
\text { Data normal }\end{array}$ \\
\hline $\begin{array}{l}2 . \\
3 .\end{array}$ & $\begin{array}{l}\text { Homogenitas } \\
\text { Hipotesis }\end{array}$ & $\begin{array}{c}\text { Levene's } \\
\text { Paired Sample T-Test }\end{array}$ & $\begin{array}{l}\text { Sig }=0,428 \\
\text { Sig }=0,000\end{array}$ & $\begin{array}{l}\text { Sig }>0,05 \\
\text { Sig }<0,05\end{array}$ & $\begin{array}{c}\text { Data homogen } \\
\text { Hasil tidak sama (berbeda) }\end{array}$ \\
\hline
\end{tabular}

Hasil perhitungan $N$-gain ternormalisasi diperoleh rata-rata kenaikan KPS dari 32 orang siswa adalah 0,58 dan 0,30 untuk kemampuan mengevaluasi siswa.
Keduanya termasuk dalam kategori sedang. Hasil analisis kelayakan, efektivitas, dan hipotesis terkait modul, maka dapat dikatakan bahwa modul berbasis RPS disertai 
concept mapping tipe network tree layak, efektif, dan berpengaruh terhadap KPS dan kemampuan mengevaluasi siswa. Parmin (2012) menyatakan bahwa keuntungan yang diperoleh dari pembelajaran dengan penerapan modul adalah menumbuhkan motivasi belajar siswa karena memudahkan memperoleh informasi pembelajaran, dapat mengetahui mana yang telah berhasil dan pada bagian modul yang mana mereka belum berhasil, serta bahan pelajaran terbagi lebih merata.

Kenaikan KPS dan kemampuan mengevaluasi siswa dikarenakan selama proses pembelajaran siswa dituntut untuk belajar secara aktif. Haryono (2006) menyatakan bahwa model pembelajaran yang mengintegrasikan KPS ke dalam sistem penyajian materi secara terpadu menekankan pada proses pencarian pengetahuan dari pada transfer pengetahuan, siswa dipandang sebagai subjek belajar yang perlu dilibatkan secara aktif dalam proses pembelajaran, dan guru hanyalah seorang fasilitator secara signifikan efektif untuk meningkatkan kemampuan proses sains siswa. Relevan dengan Brunner dalam Dahar (1989: 103) menganggap bahwa belajar penemuan sesuai dengan pencarian pengetahuan secara aktif oleh manusia, dengan sendirinya memberikan hasil yang paling baik.

Model RPS terdiri atas 5 tahapan yaitu: read and think, explore and plan, select strategy find and answer, dan reflect and extend (Krulik dan Rudnick, 1996). Setiap langkah-langkah pembelajaran menuntut siswa untuk selalu aktif dalam menggunakan keterampilan proses sainsnya yang meliputi: kemampuan mengamati, mengajukan pertanyaan, berhipotesis, menggunakan alat dan bahan, merencanakan percobaan, melakukan percobaan, menafsirkan, dan mengkomunikasikan. Kegiatan tersebut membimbing siswa mengkonstruksi sendiri pengetahuan di dalam proses pembelajaran. Siswa harus aktif melakukan kegiatan, aktif berpikir, menyusun konsep, dan mengenali serta menyimpulkan tentang halhal yang sedang atau telah dipelajari. Relevan dengan Suciati (2010), yang menyatakan bahwa pembelajaran biologi yang lebih menekankan pada keterampilan proses memungkinkan siswa dapat terlibat aktif secara intelektual, manual, dan sosial.

Salah satu jenis peta konsep yang mempermudah siswa dalam mendalami materi dan mempelajari bidang studi lebih bermakna adalah concept mapping tipe network tree yang cocok digunakan untuk menunjukkan informasi sebab-akibat, dan adanya suatu hierarki, serta prosedur yang bercabang yang akan lebih memudahkan dalam proses pembuatan dan juga proses penilaiannya (Nur dalam Trianto, 2010: 161). Concept mapping tipe network tree cocok diterapkan pada materi pencemaran lingkungan yang saling berkaitan antar konsep karena penyusunan concept mapping mengarahkan siswa untuk mampu menghubungkan antar konsep, sehingga tidak akan terjadi miss konsepsi (kesalah pahaman). Relevan dengan Eppler (2006) yang menyatakan bahwa visualisasi concept mapping yang berbeda format dapat digunakan sebagai cara-cara yang saling melengkapi untuk meningkatkan motivasi, perhatian, pemahaman, dan daya ingat. Concept mapping adalah strategi yang layak untuk membantu peserta didik dalam menulis proses perencanaan, sehingga meningkatkan kemampuan belajarnya (Lee, 2013). Perpaduan antara bahan ajar, model, dan teknik pembelajaran yang tepat dapat mencapai tujuan pembelajaran biologi.

Berdasarkan hasil uji lapangan diperoleh saran dari siswa untuk perbaikan revisi tahap III guna penyempurnaan modul, yaitu lebih memperjelas gambar. Produk modul yang telah dilakukan uji kelayakan dan efektivitas selanjutnya disebarluaskan melalui tahap diseminasi dan implementasi. Tahap diseminasi dilakukan di kabupaten Klaten yang meliputi 5 sekolah, yaitu: SMAN Wonosari, SMAN Polanharjo, SMAN Ceper, SMAN Jatinom, dan SMA Muhammadiyah 2 Klaten, sedangkan diseminasi di kabupaten Surakarta meliputi 2 sekolah, yaitu: SMAN 5 Surakarta dan SM Al-Firdaus.

\section{KESIMPULAN DAN REKOMENDASI}

Karakteristik modul biologi berbasis RPS disertai concept mapping tipe network tree pada materi pencemaran lingkungan untuk memberdayakan keterampilan proses sains dan kemampuan mengevaluasi yaitu: a. modul dikembangkan menggunakan pendekatan penelitian dan pengembangan yang dikenal sebagai Research and Development (R\&D) yang merujuk pada modifikasi model Borg dan Gall (research and information collecting, planning, develop preliminary form of product, preliminary field testing, main product revision, main field testing, operational product revision, operational field, final product revision dan dissemination and Implementasion); b. modul dikembangkan berdasarkan sintaks RPS yang terdiri atas: 1) read and think; 2) explore and plan; 3) select strategy; 4) find and answer; dan 5) reflect and extend; c. modul disertai dengan concept mapping tipe network tree sebagai teknik perluasan dan penguatan konsep; d. kegiatan pembelajaran dalam modul dapat memberdayakan keterampilan proses sains dan kemampuan menge-valuasi siswa.

Kelayakan modul biologi berbasis RPS disertai concept mapping tipe network tree pada materi pencemaran lingkungan untuk memberdayakan keterampilan proses sains dan kemampuan mengevaluasi setelah dilakukan uji coba pada setiap tahap diperoleh rata-rata 3,27 dengan kategori sangat baik, sehingga dinyatakan layak.

Modul biologi berbasis RPS disertai concept mapping tipe network tree pada materi pencemaran lingkungan efektif memberdayakan keterampilan proses sains dengan hasil $N$-gain score sebesar 0,58 dengan kategori sedang. Modul biologi berbasis RPS disertai concept mapping tipe network tree pada materi pencemaran lingkungan efektif memberdayakan kemampuan mengevaluasi dengan hasil $N$-gain score sebesar 0,30 dengan kategori sedang.

\section{DAFTAR PUSTAKA}

Borg, Walter R., Meredith D. Gall. 1983. Education Research, An Introduction. New York: Longman Inc. Choksy 
Crebert, G., Patrick, C.-J., Cragnolini, V., Smith, C., Worsfold, K., and Webb, F. 2011. Critical Evaluation Skills Toolkit. Griffith University

Dahar, R. W. 1989. Teori-teori Belajar. Jakarta: Erlangga

Eppler, M. J. 2006. A Comparison Between Concept Maps, Mind Maps, Conceptual Diagrams, and Visual Metaphors as Complementary Tools for Knowledge Construction and Sharing. Palgrave-Journals. $202-210$

Haryono. 2006. Model Pembelajaran Berbasis Peningkatan Keterampilan Proses Sains. Jurnal Pendidikan Dasar. Vol. $7(1)$

Krulik, Stephen, and Jesse A. R. 1996. The New Sourcebook For Teaching Reasoning And Problem Solving In Junior And Senior High School. United States of America: Allyn \& Bacon.

Lee, Y. 2013. Collaborative Concept Mapping as a Pre-Writing Strategy For L2 Learning: A Korean Application. International Journal of Information and Education Technology. Vol. 3 (2)

Parmin, E. Peniati. Pengembangan Modul Mata Kuliah Strategi Belajar Mengajar IPA Berbasis Hasil Penelitian Pembelajaran. Jurnal JPII 1 (1) (2012) 8-15

Rustaman, N. 2005. Strategi Belajar Mengajar Biologi. Malang: UM PRESS

Trianto. 2010. Mendesain Model Pembelajaran Inovatif Progresif: Konsep Landasan Dan Implementasinya Pada Kurikulum Tingkat Satuan Pendidikan (KTSP). Jakarta: Kencana

Yuniastuti, E. 2013. Upaya Peningkatan Keterampilan Proses Dan Hasil Belajar Biologi Dengan Pendekatan Pembelajaran Jelajah Alam Sekitar Pada Siswa Kelas VII SMP Kartika V-1 Balikpapan. Jurnal Socioscientia Kopertis Wilayah XI Kalimantan. Vol 5. (1) 